\title{
PERANTI BAHASA INDONESIA DALAM WACANA KAMPANYE PARTAI POLITIK PESERTA PEMILIHAN UMUM TAHUN 2019
}

\author{
INDONESIAN LANGUAGE DEVICES IN THE CAMPAIGN DISCOURSE OF \\ POLITICAL PARTIES PARTICIPATING IN THE 2019 GENERAL ELECTION
}

\author{
${ }^{1}$ Sudarmini, ${ }^{2}$ Sudaryanto, ${ }^{3}$ Septina Rahayu \\ ${ }^{4}$ Tutut Romania, ${ }^{5}$ Eka Nur Indah Maslakhah \\ 1, 2, 3, 4, 5Universitas Ahmad Dahlan \\ 13sudarmini@pbsi.uad.ac.id, 22sudaryanto@pbsi.uad.ac.id, ${ }^{3}$ septinarahayu02@gmail.com, \\ 4tututramaniya@gmail.com, 5 ekanurindah56@gmail.com
}

\begin{abstract}
Abstrak
Partai politik (parpol) peserta Pemilihan Umum (Pemilu) 2019 melakukan promosi diri guna mendulang suara di seluruh wilayah Indonesia. Salah satu cara promosi diri itu ialah membuat wacana kampanye yang memanfaatkan peranti bahasa Indonesia. Kajian ini bertujuan untuk mendeskripsikan ragam peranti bahasa Indonesia dalam wacana kampanye parpol peserta Pemilu 2019. Data kajian ini berupa alat peraga kampanye (APK) parpol peserta Pemilu 2019 berjumlah 16 buah, khususnya parpol non-daerah Aceh. Metode pengumpulan data yang digunakan adalah metode observasi dengan teknik baca dan catat. Teknik analisis data yang digunakan adalah teknik analisis konten (content analysis). Hasil penelitian menunjukkan bahwa ragam peranti bahasa Indonesia dalam wacana kampanye parpol peserta Pemilu 2019 terdiri atas slogan, repetisi, rima, singkatan, akronim, deiksis persona, nama diri, nama jabatan, dan nama parpol.
\end{abstract}

Kata Kunci: peranti bahasa Indonesia, wacana kampanye, partai politik, Pemilu 2019.

\begin{abstract}
Political parties (political parties) participating in the General Election (Election) 2019 conduct selfpromotion to gain votes in all regions of Indonesia. One way of self-promotion is to make campaign discourses that use Indonesian language devices. This study aims to describe the variety of Indonesian language devices in the political party campaign discourse participating in the 2019 Election. This study data in the form of campaign props (APK) of political parties participating in the 2019 Election amounted to 16 pieces, especially non-regional political parties in Aceh. The data collection method used is an observation method with reading and recording techniques. The data analysis technique used is content analysis technique. The results showed that the variety of Indonesian language tools in the campaign discourse of political parties participating in the 2019 Election consisted of slogans, repetitions, rhymes, abbreviations, acronyms, personal deixis, self names, position names, and political party names.
\end{abstract}

Keywords: Indonesian devices, campaign discourse, political parties, Pemilu 2019

\section{PENDAHULUAN}

Pemilihan Umum (Pemilu) 2019 merupakan salah satu bukti bahwa Indonesia sebagai negara penganut sistem demokrasi. Kegiatan politik selama lima tahun sekali itu diikuti oleh partai politik (parpol) dengan jumlah yang relatif berbeda antara periode yang satu dan periode yang lainnya. Sebagai contoh, Pemilu 2019 ini diikuti oleh 16 parpol, sedangkan Pemilu 2014 diikuti oleh 10 parpol, kemudian Pemilu 2009 (34 parpol), dan Pemilu 2004 (24 parpol). Dari contoh tersebut, dapat disimpulkan bahwa jumlah parpol peserta Pemilu sering 
mengalami perubahan antara periode yang satu dan periode yang lainnya. Hal itu disebabkan oleh banyak faktor, salah satunya ialah faktor perpecahan internal antarpengurus. Contohnya, Partai Golkar yang mengalami perpecahan internal sehingga memunculkan sejumlah parpol, seperti Partai Hanura, Partai Nasdem, Partai Berkarya, Partai Gerindra, dan Partai Perindo.

Kembali ke konteks Pemilu 2019, keenam belas parpol peserta Pemilu 2019 melakukan promosi diri guna mendulang suara di seluruh wilayah Indonesia. Salah satu promosi diri itu ialah membuat wacana kampanye yang memanfaatkan peranti bahasa Indonesia. Di antara banyaknya peranti bahasa Indonesia itu, slogan dimanfaatkan oleh parpol dalam alat peraga kampanye (APK)-nya. Mengutip Kamus Besar Bahasa Indonesia (KBBI) Daring (2016), slogan adalah (1) perkataan atau kalimat pendek yang menarik atau mencolok dan mudah diingat untuk memberitahukan atau mengiklankan sesuatu, seperti Solo Berseri (bersih, sehat, indah, rapi) dan (2) perkataan atau kalimat pendek yang menarik, mencolok, dan mudah diingat untuk menjelaskan tujuan suatu ideologi golongan, organisasi, partai politik, dan sebagainya. Slogan di dalam APK Partai Kebangkitan Bangsa (PKB) adalah Indonesia Maju Labir Batin.

Selain slogan, ada pula repetisi, rima, singkatan, akronim, dan deiksis persona yang termasuk ke dalam peranti bahasa Indonesia. Menurut KBBI Daring (2016), repetisi adalah ulangan, latihan, atau gaya bahasa yang menggunakan kata kunci yang terdapat di awal kalimat untuk mencapai efek tertentu dalam penyampaian makna ulangan (sandiwara dan sebagainya). Sementara itu, menurut KBBI Daring (2016), rima adalah penggulangan bunyi yang berselang, baik di dalam larik sajak maupun pada akhir sajak yang berdekatan. Berikutnya, menurut KBBI Daring (2016), singkatan adalah hasil menyingkat (memendekkan) berupa huruf atau gabungan huruf (misalnya DPR, KKN, yth., dan sebagainya., dan hlm.). Selanjutnya, menurut KBBI Daring, akronim adalah kependekan yang berupa gabungan huruf atau suku kata atau bagian lain yang ditulis dan dilafalkan sebagai kata yang wajar (misalnya ponsel telepon seluler, sembako sembilan bahan pokok, dan Kemendikbud Kementerian Pendidikan dan Kebudayaan). Menurut KBBI Daring (2016), deiksis adalah hal atau fungsi menunjuk sesuatu di luar bahasa; kata yang mengacu kepada persona, waktu, dan tempat suatu tuturan. Deiksis persona adalah hal yang menjadi fokus dalam tulisan ini.

Di samping itu, ada pula yang terkait dengan nama diri, nama jabatan, dan nama parpol. Menurut KBBI Daring (2016), nama diri adalah nama untuk menyebut diri seseorang, benda, tempat tertentu, dan sebagainya. Sementara itu, nama jabatan adalah nama pekerjaan (tugas) dalam pemerintahan atau organisasi. Selanjutnya, nama parpol adalah nama sebuah partai politik. Dalam konteks tulisan ini, parpol yang dimaksudkan ialah parpol peserta Pemilu 2019 yang terdiri atas 16 parpol nasional dan empat parpol lokal Aceh. Namun demikian, APK yang diteliti sebagai wacana kampanye parpol dalam konteks tulisan ini ialah APK dari 16 parpol nasional, sedangkan APK parpol lokal Aceh tidak diteliti.

Terkait itu, sejumlah kajian yang berkaitan dengan Pilkada 2018 dan Pemilu 2019 telah muncul, seperti Abdurachman, dkk. (2019), Amalia (2019), Fauzi (2019), Fitria (2019), Habibi (2019), Handini, dkk. (2019), Muhtadi (2019), Novadila, dkk. (2019), Nursalim (2019), Priandi \& Roisah (2019), Putra, dkk. (2019), Rosyid (2019), Sari, dkk. (2019), Siregar (2019), Sudaryanto \& Wijayanti (2019), Susanto (2019), dan Zuhro (2019). Ketujuh belas kajian itu 
dihasilkan oleh pakar bidang komunikasi politik dan ilmu politik terkemuka, seperti Burhanuddin Muhtadi (Direktur Eksekutif Indikator Politik Indonesia) dan R. Siti Zuhro (Profesor Riset pada Pusat Penelitian Politik Lembaga Ilmu Pengetahuan Indonesia-LIPI). Namun demikian, hal penting terkait peranti bahasa Indonesia dalam wacana kampanye parpol peserta Pemilu 2019 belum ditulis; oleh karena itu, kajian ini akan berfokus ke arah itu.

\section{METODE PENELITIAN}

Metode penelitian yang digunakan dalam penelitian ini adalah metode kualitatif yang bersifat deskriptif. Deskripsi merupakan gambaran ciri-ciri data secara akurat sesuai dengan sifat alamiah itu sendiri. Dalam penelitian ini, data yang dianalisis adalah alat peraga kampanye (APK) parpol peserta Pemilu 2019 sebanyak 16 buah parpol nasional. Parpol lokal di daerah Aceh tidak dipilih atau diteliti di dalam penelitian ini. Subjek penelitian ini adalah APK parpol peserta Pemilu 2019. Adapun objek penelitian ini adalah peranti bahasa Indonesia mencakup slogan, repetisi, rima, singkatan, akronim, persuasi, deiksis persona, nomor urut, nama diri, nama jabatan, dan nama parpol.

Pengumpulan data dalam penelitian ini menggunakan peneliti sendiri sebagai instrumen utama (buman instrumen). Hal ini sejalan dengan pemikiran bahwa tidak adanya kemungkinan memakai alat lain selain manusia (Djajasudarma, 2006). Data yang dikumpulkan adalah peranti bahasa Indonesia dalam wacana kampanye parpol peserta Pemilu 2019. Data dibaca dan dicatat dengan menggunakan kartu data, yaitu bagian deskripsi dan refleksi. Keabsahan data dalam penelitian kualitatif dengan dua konsep, yaitu konsep kesahihan (validitas) dan konsep keterandalan (reliabilitas). Dalam penelitian ini digunakan validitas semantik dan reliabilitas melalui cara baca dan kaji ulang. Untuk memperoleh data yang terpercaya dilakukan tiga cara, yaitu ketekunan pengamatan, triangulasi, dan pengecekan teman sejawat.

Selanjutnya, teknik analisis data yang digunakan dalam penelitian ini adalah teknik kajian isi (content analysis). Definisi teknik kajian isi adalah teknik penelitian yang dimanfaatkan untuk menarik kesimpulan yang replikatif dan sahih dari data atas dasar konteksnya (Krippendorf, 1980). Peneliti melakukan penyusunan dan kategorisasi. Data yang terkumpul kemudian dipilah-pilah dan dikategorisasikan. Dalam konteks penelitian ini, data dikategorisasikan ke dalam sembilan jenis peranti bahasa Indonesia meliputi slogan, repetisi, rima, singkatan, akronim, deiksis persona, nama diri, nama jabatan, dan nama parpol.

\section{HASIL DAN PEMBAHASAN}

Bagian ini memuat pemaparan hasil penelitian dan pembahasan tentang peranti bahasa Indonesia dalam wacana kampanye parpol peserta Pemilu 2019. Peranti bahasa Indonesia itu meliputi slogan, repetisi, rima, singkatan, akronim, deiksis persona, nama diri, nama jabatan, dan nama parpol.

\section{Slogan}

Salah satu peranti bahasa Indonesia dalam wacana kampanye parpol peserta Pemilu 2019 adalah slogan. Sesuai dengan definisi slogan di atas, wacana kampanye parpol peserta 
Pemilu 2019 memuat slogan. Sebagai contoh, Partai Kebangkitan Bangsa memiliki slogan Indonesia Maju Labir Batin. Melalui slogan tersebut, PKB berharap Indonesia mengalami pemajuan secara lahir dan batin. Contoh lainnya sebagai berikut.

(1) Rumah Kebangsaan Indonesia Raya (PDI-P),

(2) Suara Rakyat Suara Golkar (Partai Golkar),

(3) Ayo Lebih Baik (PKS),

(4) Untuk Indonesia Sejahtera (Partai Perindo),

(5) Indonesia Maju (PPP),

(6) Hanura, dengan Hati Nurai Bekerja Keras, Berinovasi Demi Kesejahteraan Rakyat (Partai Hanura), dan

(7) Wujudkan 14 Prioritas Demokrat untuk Rakyat (Partai Demokrat).

Partai Demokrasi Indonesia Perjuangan (PDI-P) memiliki slogan yang bersifat metaforis, yaitu Rumah Kebangsaan Indonesia Raya. Partai Golkar memiliki slogan yang bersifat repetitif, yaitu Suara Rakyat Suara Golkar yang merujuk ke peribahasa Latin Vox Dei Vox Populi, artinya 'suara Tuhan, suara rakyat'. Sementara itu, Partai Keadilan Sejahtera (PKS) memiliki slogan Ayo Lebih Baik, Partai Persatuan Indonesia (Partai Perindo) memiliki slogan Untuk Indonesia Sejabtera, dan Partai Hati Nurani Rakyat (Partai Hanura) memiliki slogan Hanura, dengan Hati Nurani Bekerja Keras, Berinovasi Demi Kesejabteraan Rakyat. Berikutnya, Partai Demokrat (PD) memiliki slogan Wujudkan 14 Prioritas Demokrat untuk Rakyat, angka 14 merupakan nomor urut Partai Demokrat pada Pemilu 2019.

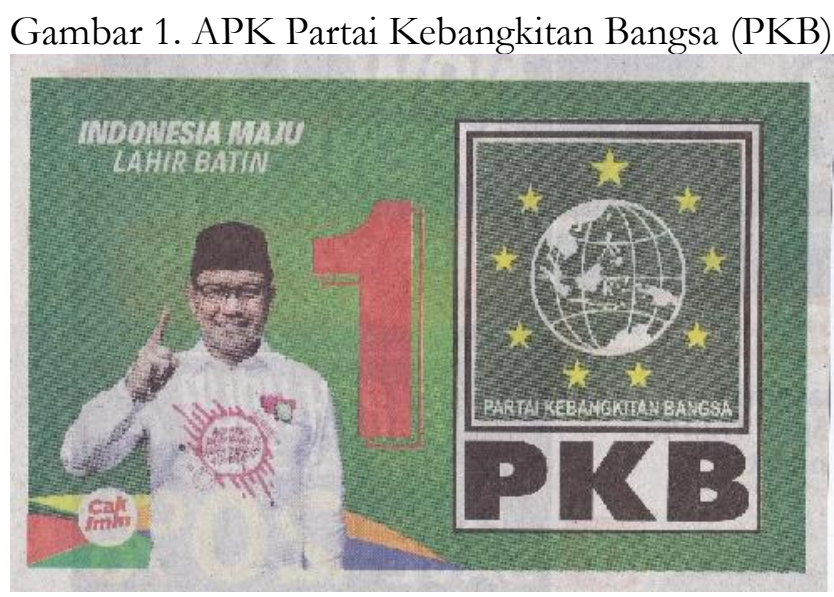

\section{Repetisi}

Salah satu peranti bahasa Indonesia dalam wacana kampanye parpol peserta Pemilu 2019 adalah repetisi. Sesuai dengan definisi repetisi di atas, wacana kampanye parpol peserta Pemilu 2019 memuat repetisi. Sebagai contoh, Partai Golkar memiliki slogan yang sifat repetitif, yaitu Suara Rakyat Suara Golkar. Slogan itu memuat kata Suara yang diulang sebanyak dua kali. Selain itu, ada pula Partai Solidaritas Indonesia (PSI) dengan slogan Anti Korupsi Anti Poligami, Partai Amanat Nasional (PAN) dengan slogan Bela Rakyat Bela Umat, dan Partai Bulan Bintang (PBB) dengan slogan Bela Islam, Bela Rakyat, Bela NKRI. 
Gambar 2. APK Partai Amanat Nasional (PAN)

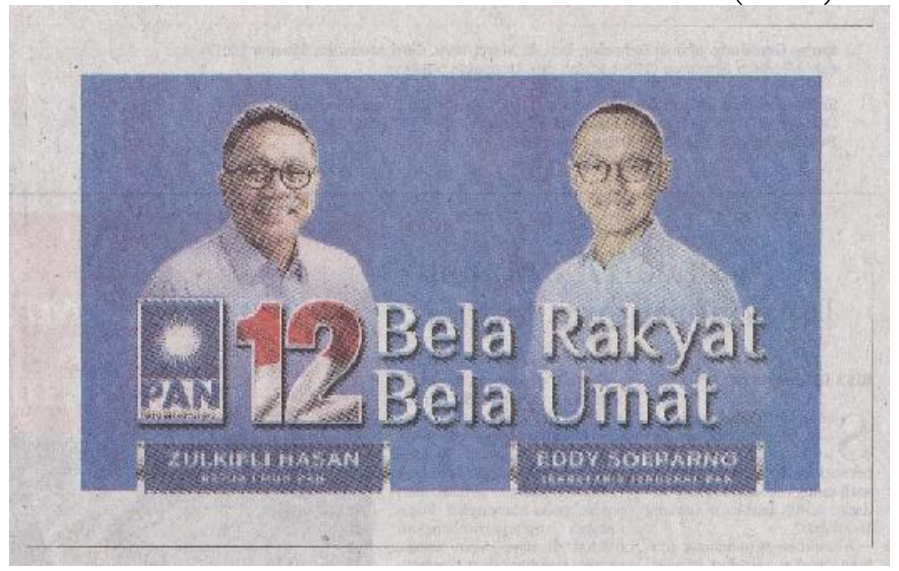

\section{Rima}

Salah satu peranti bahasa Indonesia dalam wacana kampanye parpol peserta Pemilu 2019 adalah rima. Sesuai dengan definisi rima di atas, wacana kampanye parpol peserta Pemilu 2019 memuat rima. Sebagai contoh, Partai Demokrasi Indonesia Perjuangan (PDIP) memiliki slogan yang memuat rima atau bunyi /a/, Kerja Kita Kerja Indonesia. Kemudian Partai Nasional Demokrat (Partai Nasdem) memiliki slogan yang memuat rima atau bunyi /u/, Jokowi Presidenku Nasdem Partaiku. Selanjutnya, Partai Solidaritas Indonesia (PSI) memiliki slogan yang memuat rima atau bunyi /i/, Anti Korupsi Anti Poligami dan Partai Amanat Nasional (PAN) memiliki slogan yang memuat rima atau bunyi /t/, Bela Rakyat Bela Umat.

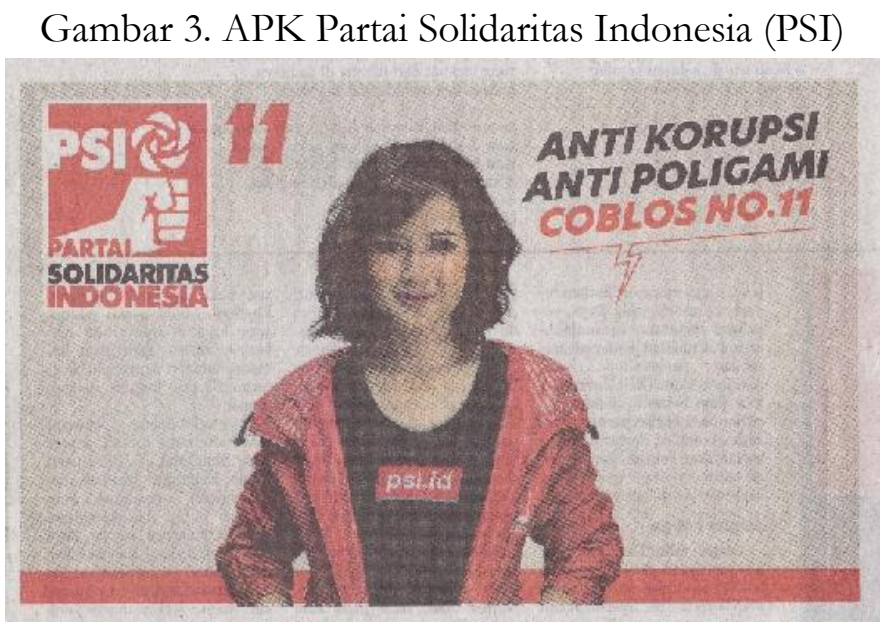

\section{Singkatan}

Salah satu peranti bahasa Indonesia dalam wacana kampanye parpol peserta Pemilu 2019 adalah singkatan. Sesuai dengan definisi singkatan di atas, wacana kampanye parpol peserta Pemilu 2019 memuat singkatan berupa nama-nama parpol, seperti Partai Kebangkitan Bangsa (PKB), Partai Demokrasi Indonesia Perjuangan (PDI-P), Partai 
Keadilan Sejahtera (PKS), Partai Persatuan Pembangunan (PPP), Partai Solidaritas Indonesia (PSI), Partai Bulan Bintang (PBB), dan Partai Keadilan dan Persatuan Indonesia (PKPI).

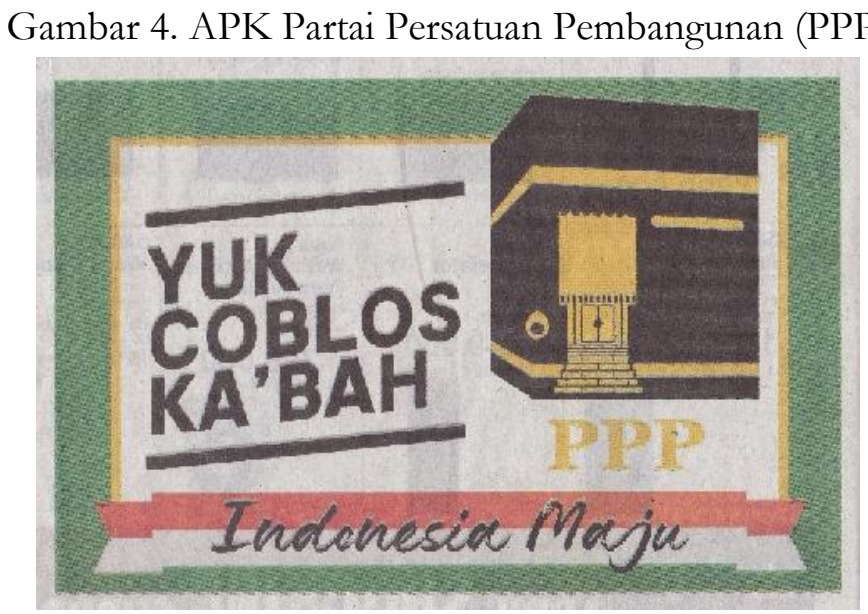

\section{Akronim}

Salah satu peranti bahasa Indonesia dalam wacana kampanye parpol peserta Pemilu 2019 adalah akronim. Sesuai dengan definisi akronim di atas, wacana kampanye parpol peserta Pemilu 2019 memuat akronim berupa nama-nama parpol, seperti Partai Nasional Demokrat (Partai Nasdem), Partai Gerakan Indonesia Raya (Partai Gerindra), Partai Gerakan Perubahan Indonesia (Partai Garuda), Partai Persatuan Indonesia (Partai Perindo), Partai Hati Nurani Rakyat (Partai Hanura), Partai Golongan Karya (Partai Golkar). Tata akronim yang digunakan ialah penggunaan suku kata pertama pada kata pertama dan kata kedua atau lebih. Misalnya, Hanura terdiri atas tiga kata, Hati Nurani Rakyat. Suku kata pertama pada kata hati, nurani, dan rakyat diambil dan digabungkan menjadi satu konsep.

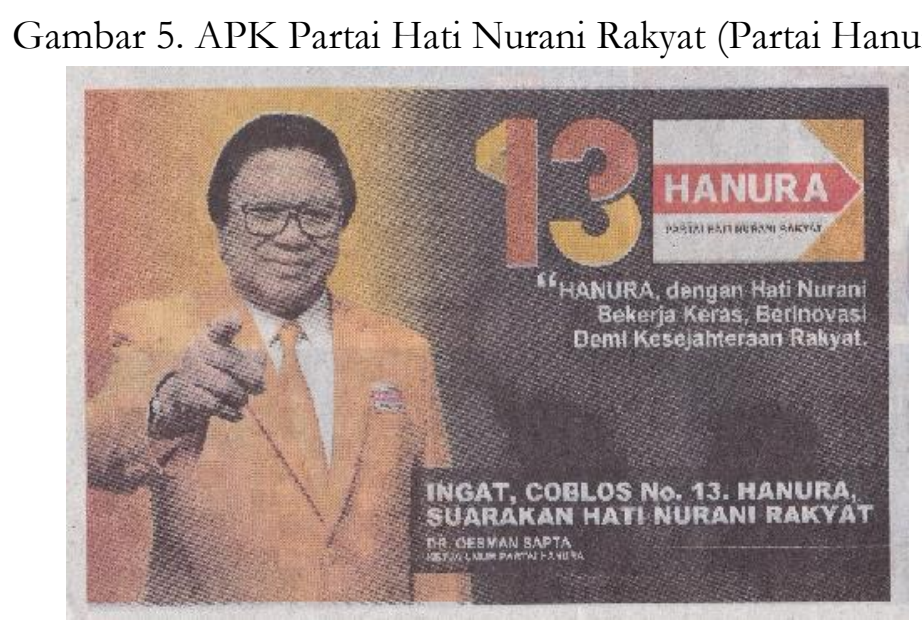

\section{Deiksis Persona}

Salah satu peranti bahasa Indonesia dalam wacana kampanye parpol peserta Pemilu 2019 adalah deiksis. Dalam konteks tulisan ini, yang dipilih ialah deiksis persona, yaitu 
kategori deiktis yang bersangkutan dengan partisipan dalam situasi bahasa. Mengutip Kridalaksana (2011), deiksis persona terbagi deiksis persona pertama (aku, -ku, saya), deiksis persona kedua (kamu, -mu, kalian), deiksis persona ketiga (ia, -nya, mereka, beliau), deiksis persona pertama jamak eksklusif (kami), dan deiksis persona pertama jamak inklusif (kita). Wacana kampanye parpol peserta Pemilu 2019 memuat deiksis persona, seperti persona deiksis pertama (-ku) pada slogan Partai Nasdem Jokowi Presidenku Nasdem Partaiku, persona deiksis kedua (kalian) pada slogan Partai Perindo Ayo, generasi muda, Indonesia membutubkan kalian, dan persona pertama jamak inklusif (kita) pada slogan PDI-P Kerja Kita Kerja Indonesia.

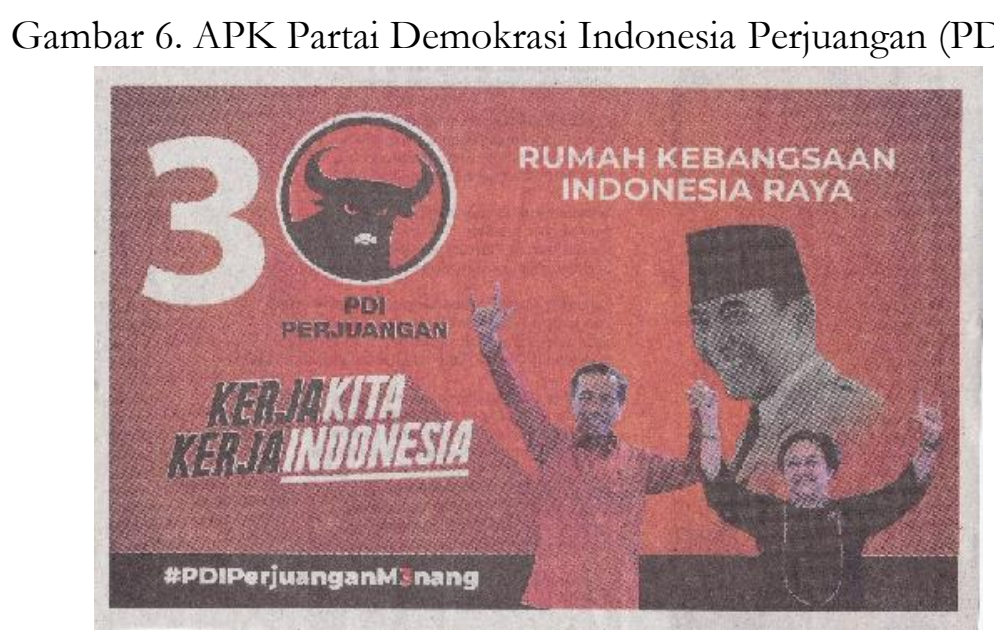

\section{Nama Diri}

Salah satu peranti bahasa Indonesia dalam wacana kampanye parpol peserta Pemilu 2019 adalah nama diri. Sesuai dengan definisi nama diri di atas, wacana kampanye parpol peserta Pemilu 2019 memuat nama diri ketua umum parpol sebagai berikut.

(8) Zulkifli Hasan (PAN),

(9) Eddy Soeparno (PAN),

(10) Cak Imim (PKB),

(11) Diaz Hendropriyono (PKPI),

(12) Prof. Dr. Yusril Ihza Mahendra (PBB),

(13) Habib Dr. Salim Segaf Aljufri, M.A. (PKS),

(14) Moh. Sohibul Iman, Ph.D. (PKS),

(15) Dr. Oesman Sapta (Partai Hanura), dan

(16) Hary Tanoesoedibjo (Partai Perindo). 


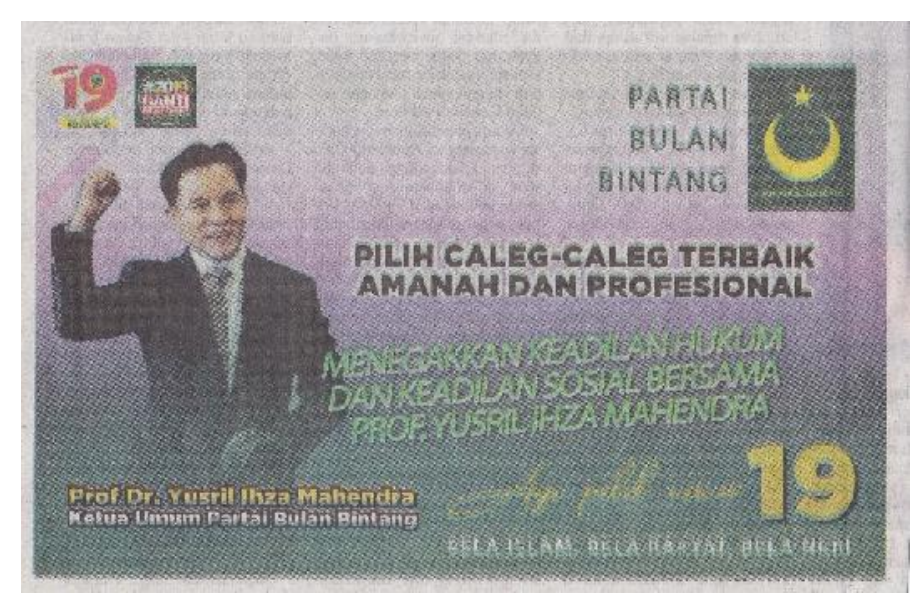

\section{Nama Jabatan}

Salah satu peranti bahasa Indonesia dalam wacana kampanye parpol peserta Pemilu 2019 adalah nama jabatan. Sesuai dengan definisi nama jabatan di atas, wacana kampanye parpol peserta Pemilu 2019 memuat nama-nama jabatan, seperti Ketua Umum Partai Bulan Bintang, Ketua Majelis Syuro PKS, Presiden PKS, Ketua Umum Partai Hanura, Ketua Umum PKPI, Ketua Umum PAN, dan Sekretaris Jenderal PAN.

Gambar 8.

APK Partai Keadilan Sejahtera (PKS)

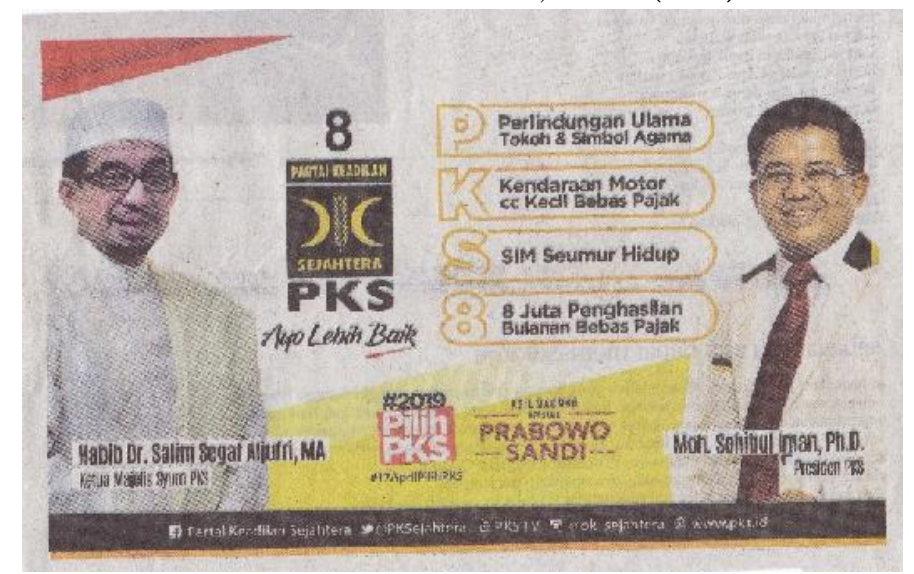

\section{Nama Parpol}

Salah satu peranti bahasa Indonesia dalam wacana kampanye parpol peserta Pemilu 2019 adalah nama parpol. Sesuai dengan definisi di atas, wacana kampanye parpol peserta Pemilu 2019 memuat nama parpol, seperti Partai Kebangkitan Bangsa (nomor urut 1), Partai Gerakan Indonesia Raya (2), Partai Demokrasi Indonesia Perjuangan (3), Partai Golkar (4), Partai Nasdem (5), Partai Garuda (6), Partai Berkarya (7), Partai Keadilan Sejahtera (8), Partai Persatuan Indonesia (9), Partai Persatuan Pembangunan (10), Partai Solidaritas Indonesia (11), Partai Amanat Nasional (12), Partai Hati Nurani Rakyat (13), Partai Demokrat (14), Partai Bulan Bintang (19), dan Partai Keadilan dan Persatuan Indonesia (20). 


\section{SIMPULAN}

Berdasarkan uraian pembahasan di atas, maka diperoleh simpulan sebagai berikut. Peranti bahasa Indonesia dalam wacana kampanye parpol peserta Pemilu 2019 terdiri atas slogan, repetisi, rima, singkatan, akronim, deiksis persona, nama diri, nama jabatan, dan nama parpol. Peranti-peranti tersebut digunakan secara baik dalam wacana kampanye parpol peserta Pemilu 2019 oleh para kreator dan/atau pihak kampanye parpol. Salah satu tujuan penggunaan peranti-peranti bahasa Indonesia dalam wacana kampanye parpol itu ialah untuk mendulang suara di seluruh wilayah di Indonesia, khususnya dalam kontestasi Pemilu 2019.

\section{DAFTAR PUSTAKA}

Abdurachman, H., Riyanti, R., \& Nugraha, R. A. (2019). Kuota perempuan di DPRD Jawa Tengah pada Pemilu 2014 dan Pemilu 2019. Perspektif Hukum, 19(1), 124-149.

Amalia, L. S. (2019). Upaya mobilisasi perempuan melalui narasi simbolik 'emak-emak dan ibu bangsa' pada Pemilu 2019. Jurnal Penelitian Politik, 16(1), 17-33.

Djajasudarma, T. F. (2006). Metode linguistik: Ancangan dan kajian. Bandung: Refika Aditama.

Fauzi, A. M. (2019). Perilaku pemilih menjelang Pemilu 2019. Journal of Islamic Civilization, 1(1), $40-48$.

Fitria, S. A. (2019). Analisis framing pemberitaan deklarasi kampanye damai Pemilihan Presiden 2019 di Liputan6.com dan Tempo.co. (Skripsi, UIN Sunan Ampel Surabaya, Surabaya).

Habibi, M. R. (2019). Partai Keadilan Sejahtera (PKS) dalam sorotan media di Indonesia. Jurnal Tapis: Jurnal Teropong Aspirasi Politik Islam, 15(1), 115-141.

Handini, V. A., Nugroho, W., \& Nur'afifah, O. (2019). Transformasi media kampanye dalam konstelasi Pilpres Indonesia Tahun 2009-2019. Dalam Proceeding Conference On Communication and News Media Studies 1, 34-45. URL: http://proceeding.umn.ac.id/index/php/COMNEWS/article/view/1078.

Krippendorf, K. (1980). Content analysis: An introduction to its methodology. Beverly-Hills: Sage Publications.

Muhtadi, B. (2019). Politik uang dan new normal dalam Pemilu pasca-Orde Baru. Integritas: Jurnal Antikorupsi, 5(1), 55-74.

Novadila, A., Said, M. P., \& Miranda. (2019). Peran radio lokal sebagai agen sosialisasi politik pada kalangan pemilih muda di Pulau Pramuka. Wacana: Jurnal Ilmiah Ilmu Komunikasi, 18(1), 35-45.

Nursalim, M. P. (2019). Mitos di media sosial terkait Pilpres 2019. Piktorial, 1(1), 1-14.

Priandi, R. \& Roisah, K. (2019). Upaya meningkatkan partisipasi politik perempuan dalam pemilihan umum di Indonesia. Jurnal Pembangunan Hukum Indonesia, 1(1), 106-116.

Putra, I. M., Ariany, R., \& Syahrizal. (2019). Tata kelola verifikasi partai politik peserta pemilihan umum tahun 2019 di Komisi Pemilihan Umum Kota Padang. JISPO: Jurnal Ilmu Sosial dan Ilmu Politik, 9(1), 107-123.

Rosyid, H. (2019). Pelaksanaan pendidikan politik oleh DPD Partai Gerindra Jawa Timur dalam rangka menghadapi Pemilu Serentak 2019 (Studi pada DPC Partai Gerindra Kabupaten dan Kota Mojokerto). Humanis: Jurnal Ilmu-Ilmu Sosial dan Humaniora, 11(1), $29-38$. 
Sari, A. T. Y., Fitriyani, A. D., \& Said, M. P. (2019). Komunikasi interpersonal pada proses pendidikan politik pemilih pemula di Pulau Pramuka. JIKE: Jurnal Ilmu Komunikasi Efek, 2(2), 189-207.

Siregar, F. A. H. (2019). Strategi politik DPC Partai Bulan Bintang Surabaya dalam Pemilu Legislatif 2019. (Skripsi, UIN Sunan Ampel Surabaya, Surabaya).

Sudaryanto, S. \& Wijayanti, D. (2019). Strategi berbahasa calon kepala daerah pada wacana kampanye Pilkada Jawa Barat. Jurnal Membaca Bahasa dan Sastra Indonesia, 4(1), 51—58.

Susanto, A. (2019). Strategi Partai Perindo jelang Pemilu 2019. Jurnal Ilmiah Ilmu Pemerintahan, $3(2), 123-134$.

Zuhro, R. S. (2019). Demokrasi dan pemilu Presiden 2019. Jurnal Penelitian Politik, 16(1), 69_ 81. 